\title{
NorDiNa Editorial 3/2019
}

Welcome to the third issue of NorDiNa in 2019. This issue consists of seven research articles, one book review, and one In Memoriam text.

In the article "Authentic science in the classroom - students' perceptions of their experiences" by Jenny Sullivan Hellgren, the author aims to characterize students' experiences from taking part in authentic research through a project designed to increase motivation for science and understanding of research in the Swedish secondary school. Twenty-four students from three Swedish lower-secondary schools participating in the project were interviewed. The main result was that students' experiences from taking part were positive and science-related. Students' responses were also connected to the science content and to learning science.

The article "Excursions remains longer in the brain. Student's views on teaching methods in Science education" by Kari Sælemyr and Jan Egil Bjørndal deals with 10th grade students' views on teaching methods in science. The students have answered a survey on what they think is positive in science teaching and what they think could be improved. They were also asked to explain why. The answers have been analyzed using a mixed methods design. The most distinct finding was that many students express boredom and lack of well-being in the science classroom. The students' answers indicate that traditional teaching methods dominate, and that teaching methods that are considered important in science teaching, such as excursions and inquiry teaching methods, are less used. The students believed that science teaching methods that provide more use of dialogue, cooperation and activity will increase learning and well-being.

The focus in the article "About Preschool teachers work with physics in preschool" by Lina Hellberg, Susanne Thulin and Andreas Redfors is how physics content is constructed as an object of learning during preschool teachers' planning of teaching. The result of a phenomenographic analysis focusing themes of the conversation concerning the intended object of learning reveals a complex process. Occurrences in the activities with the children, available tools at the preschool, the preschool teachers' perceptions of the mission and understanding of the learning object, contribute to the construction of the learning object. All these aspects are discussed and implications for preschool practice are suggested.

The article by Iann Lundegård and Charlotta Billing is entitled "Teacher training through parallel processes focused on societal issues with scientific content. - "When is it right to kill an animal?". In this study, the authors wanted to visualize some different aspects that appeared when teacher students discussed a socio-scientific issue. Furthermore, the aim was to develop a method that could help the students to reflect on how they could arrange similar activities in their future classrooms 
within a parallel process. The data collection was carried out when the students discussed an authentic question concerning the right to kill animals. To analyse the content and meaning making that emerged in the students' discussions, the authors used practical epistemological analysis (PEA). In the results they highlight three aspects, which could be important to consider when organizing instruction around SSI in a pluralistic spirit.

In "The experiences of middle school teachers with technology and design raise some issues with respect to the new national curriculum" Sigve Ladstein presents a study of the subject Technology and Design, which has been included as a multidisciplinary subject and specific field of science in the Knowledge Promotion reform in Norway. In the study, middle school teachers were interviewed regarding their understanding of the school authorities' intentions with technology and design, and how they plan and teach this subject. The results show that the teachers generally held the view that the purpose behind technology and design is to make students' competencies meet society's needs related to engineering and science, and to motivate students to choose a scientific education. The internet and educational instruction books in science inspire the teachers, but the curriculum's competency goals hardly govern the provided education.

In their article "Adolescents' perception of scientific inquiry in nature: A drawing analysis" Piia Nuora, Jouni Välisaari and Tiina Kiviniemi aim to determine adolescents' perception of scientific inquiry (SI) in nature and the effect of a science camp on those perceptions. Eleven adolescents (aged 14 to 16) participated in the study during a science camp. The authors used pre- and post-test including open questions and drawing tasks. The campers' drawings were analyzed to assess their out-of-school perceptions related to SI. The findings suggest that the phases of SI were well known before the camp, but minor developments in campers' perceptions of the phases of SI did occur. The drawings in the post-test were generally more detailed than those in the pre-test. In particular, symbols of technology and laboratory equipment appeared more frequently after the science camp.

In their article "'But it doesn't go up into the sky!' Preschool children discuss the water cycle as illustrated in a board-and-dice game” Anneli Bergnell, Lisbeth Åberg-Bengtsson analyse 4-6-yearolds meaning-making about the water circle from a board game. Video-recorded sessions with small groups of children were used and analysed from socio-semiotic and cultural historical perspectives. The results show that even though the children referred to and made intended meaning of several of the illustrated water phenomena, it seemed difficult for them to come to grips with the water circle as such. According to the authors, this could be related to the abstract nature of the concept of evaporation.

In this issue, we also publish a book review written by Jesper Haglund on the second edition of Fysikkdidaktikk by Carl Agnell et al. Lastly, the issue contains a memorial article over professor Helge Strömdahl, the former director of the Swedish National Graduate School in Science and Technology Education (FontD), who sadly passed away in November 2018.

We hope you enjoy your reading!

Are Turmo and Carl-Johan Rundgren

Editors 


\title{
NorDiNa - Nordic Studies in Science Education
}

\author{
Editor in chief
}

Merethe Frøyland (The Norwegian Centre for Science Education, University of Oslo).

\section{Main Editors}

Are Turmo (University of Oslo, Norway)

Carl-Johan Rundgren (Stockholm University, Sweden)

\section{National Co-Editors}

Antti Laherto (University of Helsinki, Finland)

Marianne Achiam (University of Copenhagen, Denmark)

Auður Pálsdóttir (University of Iceland, Iceland)

\section{Editorial board}

Svein Sjøberg (University of Oslo, Norway)

Anita Wallin (University of Gothenburg, Sweden)

Per-Olof Wickman (Stockholm University, Sweden)

Marianne Ødegaard (University of Oslo, Norway)

Allyson Macdonald (University of Iceland, Iceland)

Jari Lavonen (University of Helsinki, Finland)

Irmeli E. Palmberg (Åbo Akademi University, Finland)

Rie Popp Troelsen (University of Southern Denmark, Denmark)

Stein Dankert Kolstø (University of Bergen, Norway)

Christina Ottander (Umeå University, Sweden)

Maija Aksela (University of Helsinki, Finland)

Birgitte Lund Nielsen (Aarhus University, Denmark)

Lars Brian Krogh (VIA University College, Denmark)

\section{Open Access Journal}

NorDiNa is available as an Open Access Journal at the following URL: www.journals.uio.no/index.php/ nordina/index. The editors encourage authors and referees to register at NorDiNas Internet site. In case of problems when register or submitting papers, please contact the editors. Nordic Studies in Science Education do not charge any fee for publication. 